Nation-State. 'Fourth World' Politics in Canada, Australia and Norway, St Johns, Newfoundland: Institute of Social and Economic Research.

Geertz, C. (1975) 'Deep play: notes on the Balinese cockfight', in The Interpretation of Cultures, London: Hutchinson.

(1983) 'Local knowledge: fact and law in comparative perspective', in Local Knowledge: Further Essays in Interpretive Anthropology, New York: Basic Books.

Kavadias, G. (1966) 'The assimilation of the scientific and technological "message" ', International Social Science Journal, 18(3).

Lienhardt, R. 'G. (1961) Divinity and Experience: the Religion of the Dinka, Oxford: Oxford University Press.

McClelland, D. G. (1961) The Achieving Society, Princeton, NJ: Van Nostrand.

Paine, R. P. B. (1970) 'Informal communication and information management', Canadian Review of Sociology and Anthropology 7(3). Schwartz, T. (1975) 'Cultural totemism: ethnic identity primitive and
modern', in G. de Vos and L. Romanucci-Ross (eds) Ethnic Identity: Cultural Contmuities and Change, Palo Alto, Calif.: Mayfield.

Strathern, M. (1984) 'The social meanings of localism', in T. Bradley and P. Lowe (eds) Locality and Rurality: Economy and Society in Rural Regions, Norwich: Geo Books.

Stuchlik, M. (1976) 'Whose knowledge?', in L. Holy (ed.) Knowledge and Behaviour, Queen's University Papers in Social Anthropology No. 1: 1-15, Belfast: Queen's University.

\section{Processes and limitations of Dogon agricultural knowledge}

Walter E. A. van Beek

\section{INTRODUCTION}

In this contribution I try to explore the effect ecological changes and pressures have had on the adaptation of the Dogon in Mali. The general angle will be that of cultural ecology, in which a particular society is viewed from the perspective of its interaction with its physical as well as social environment. This interaction is of a complex nature, and in fact constitutes the subject of this chapter. It bears some features of a system, but the coherence of the variables should not be overestimated. In any case, the interaction is not homeostatic one. Periodic upheavals of a physical nature (droughts, locusts) as well as of a socio-political nature (slave raiding, demographic growth) periodically upset any survival strategy developed by the population.

A study of adaptation and its fluctuations and changes has to focus on both the internal organization of the group and the specific characteristics of the environment. This has to be couched in a historical framework as much as possible, as the essence of adaptation is adapting to change. Of course, historical sources on the Dogon are few; one has to rely on oral tradition, climatic data over several centuries and the political history of the Nigerbend.

Adaption is, its social apsects notwithstanding, a process involving individual people, who react to their social and physical environment according to their view of the situation, their knowledge of the 'realities' they have to face. This knowledge is usually dubbed the 'perceived environment' (Hardesty 1978) and as such is thought to be the mediating factor between outside change and cultural reaction. I shall try to show that the processes of mediation are of a more complex character, as knowledge of and interaction with environment is less exclusively cognitive. The Dogon seem to work 
more through a body of practices - knowing how to do things and to react to changes, a set of practical procedures - than through a formal system of shared knowledge. This has consequences for their ways of both resisting and incorporating change; one result is that the main challenge to the Dogon local knowledge is not change in content but in scale.

\section{AN ECOLOGICAL VIEW OF DOGON HISTORY}

For the many tourists travelling though Mali, the Dogon villages huddled on the inhospitable sciee of the majestic Bandiagara escarpment present both a striking sight (and a substantial income for the Malian state) and a perennial question: how do the Dogon manage to survive in such a seemingly inhospitable environment and why did they choose such a site? Two sets of factors have shaped the Dogon predilection for their 'falaise', historical and geographical. The first was slave raiding. The Nigerbend, where the Dogon area is situated, has been scourged by continuous slave raiding. The empires of Ghana, Mali. Sonrai, the chiefs and kings of the Mossi, Sao and Fulani had a perennial hunger for slaves. For them all nonMuslims were potential slaves. Raiding was usually small-scale and catried out by merchants in a hit-and-run manner. Against this threat, the Bandiagara escarpment offered a fair defence. On the plateau the villages were built behind narrow gorges, and were only accessible on foot; at the foot of the cliff the scree offered some protection against mounted attack and from a high position there was a chance of spotting raiding parties some way off. If the danger was too great, the Dogon could flee into the caverns inside the sandstone cliff.

The second factor is water. The water situation at the plateau rim as well as at the foot is slightly better than either on the plateau or in the sandy dunes of the plains (see the illustrated cross-section). The sandstone rock holds a considerable amount of water throughout the dry season, while the floor of the scree is the lowest part of the area; a rivulet runs parallel to the falaise in the wet season.

So the plateaulands immediately bordering the rim and the valley fields closest to them offered a fair prospect for horticulturalists. The Dogon were by no means the first to settle in the falaise area Other, prehustoric, groups preceded them, known as the Tellem and the Toloy (Bedaux 1982). Their ecological situation, as far as can be gleaned from the scant data, must have been quite simlar. The Dogon arrived at the falaise towards the end of the Mali empire,

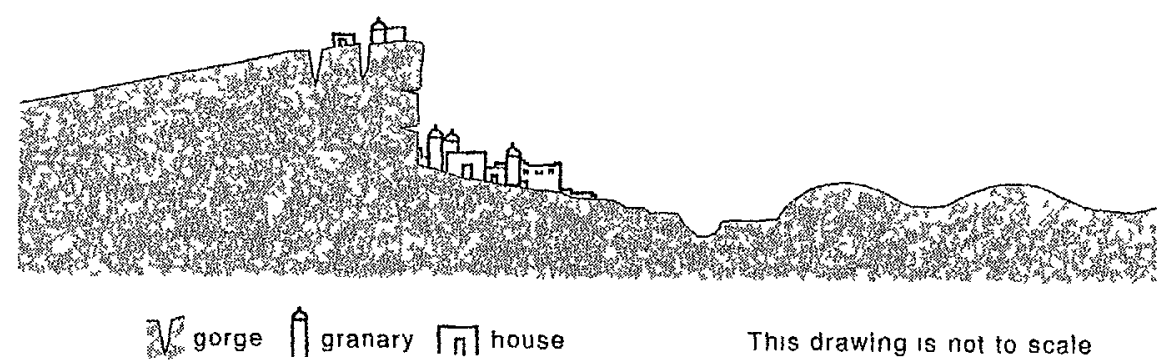

Figure 2.1 Dogon habitation: a cross-section

somewhere around the fifteenth century. They chased away the Tellem and settled in their ecological niche, cultivating millet and sorghum. Periodic droughts must have been part of their collective experience. The sixteenth to the eighteenth centuries saw at least three drought periods per century, while the nineteenth century seems to have been more generous with rain (Bryson and Murray 1977). Though in these periods some rituals may have been generated that bear a close association with drought (van Beek 1986), oral tradition does not reach further back than the nineteenth century (with a possible exception for the order of arrival at the escarpment; see Dieterlen 1942).

From the sixteenth to the nineteenth century the slave raiding pressure probably increased, as the centres of political activity came closer to the Bandiagara region. After the distant Ghana, Mali and Sonrai empires, the Mossi, Fulani and Sao were close and frequent slave raiders. Their intermediary position as merchants aggravated matters for the Dogon, as both the intensification of war and the growth of cities during the eighteenth and nineteenth centuries increased the demand for slaves in the whole of the West African Sudan. At the end of the eighteenth century the Fulani jihads. triggered by a resurgence of Islam, for a large part through Sufism, put an ever larger premium on slaves for warfare. In the nineteenth century, the relatively favourable climatic circumstances permitted large cavalries, for which great numbers of slaves and craftsmen had to be recruited to enable them to function (cf. Smaldone 1978). So in the nineteenth century insecurity was at its peak, and the pressure on the escarpment had gradually increased, when the Europeans arrived on the scene. 


\section{An anthropological critique of development}

The safety of the escarpment was a relative one for the Dogon, offering a possibility for defence but by no means a guarantee of safety. The Dogon did lose many to the raiders, though the amount is very hard to estimate. They coped with the perennial threat in several ways. First of all, they cultivated fields as close to the village and the falaise as possible. using a system of intensive horticulture on fields in sight of the village. Manuring the fields, according to local tradition, was developed at the falaise. The cultivated crops, millet and sorghum, were rotated with beans and fonio (Digitaria exilts); the latter crop may formerly have been more important than in recent times, judging by its pre-eminence in ritual. It is well suited for a situation of relative neglect, as sowing is done 'a la volé, and weeding is hardly needed; harvesting has to be done collectively (Paulme 1948). Between these main crops maize and tobacco, introduced long before the Europeans came into Africa, were cultivated; maize served as an early crop (though fonio was more important as a quick harvest in a season of hunger), while tobacco was grown in the river-bed in the dry season, using a version of pot-irrigation.

The social adaptation to the combined need for production and defence was generally an insistence on communality. The size of the villages varied from 500 to 1,000 inhabitants. Smaller villages were hard put to mobilize enough able-bodied young men; in larger ones the land pressure would force cultivation too far from the protecting scree. Work was organized as often as possible in large groups, able to defend themselves against the small bands of horsemen roaming the countryside Groups of 10 to 20 men were large enough; the farther the fields were from the village, the larger the group needed. Recruitment of groups was done in two ways: the first drew on the extended family, and the second was according to age, that is, the age of men. For the close fields an extended family was usually able to furnish labour-cum-defence, though a combination of two to four extended families, often forming the smallest gina (partrilineal segment), was a normal working unit too. The old men of the families in question co-ordinated the work, either having their people work together on one large field, or arranging that families worked on adioning fields. The old men served as look-outs from the toguna, the men's hut built high up against the mountain with an unrestricted view over the plans or the plateau.

For the larger fields, especially those further removed from the village, a larger group was recruited, consisting of men from three to five consecutive age groups. The age-class system of the Dogon
Processes and limitations of Dogon agricultural knowledge 47

had (and has) the regulation of labour as its main goal and raison d'être. One age-class of a typical Dogon village consisted of a fixed amount of able-boded males, around 50 in many cases, who gathered whenever there was communal work to be done. Clearing and weeding bush fields were some of the most important jobs. As each group was formed at the age of marriage of the boys, these communal labours also served as bride service, an important aspect of the marriage proceedings (Paulme 1948). If an age class (kadaga) worked out in the fields, several old kinsmen served as look-out in the highest toguna or - for the villages at the foot of the escarpment - up on the plateau rim. Drums served as a means of communication. The same system served when large-scale communal labour was to be done. A larger task, like digging the village well, setting out the steep paths up to the plateau or reroofing the toguna, called for more than one kadaga. Then the old men of the wards discussed the task at hand, determined the number of kadaga needed and had the town crier call upon the labourers to volunteer in. In large endeavours, beer had to be prepared in advance, as drinking was an integral part of this tye of communal labour. The maximal labour unit consists of all functioning kadaga of the whole village (in recent times supplemented with all villagers living in other settlements as well as all in-laws from the village), implying all able-bodied men up to the age of about 45 years.

The co-ordinating task of the old men was facilitated by their general position of authority; theirs was (and still is) a key position, as they control the in-fields, that is, the fields within view of the scree. All fields where permanent cultivation was possible - which were close enough to manure - were assigned to the oldest men of the village and ward, and of the clans and families. The complicated system of land rotation implied that a specific set of fields was assigned to the oldest of the village, another set to the next oldest and so on, for each section of the village as well as for the whole community. So the old men were in a position to co-ordinate and did have a definite interest in the cultivation of their fields. They usually belonged to the same age group, and could base their work on a long-standing tradition of co-operation. During a later phase their task was to be individualized, but in the pre-colonial period they seem to have decided as a body which fields were going to be cultivated, sown with what crop, and how many of what age group were going to participate. Crying out loud in front of the soundreflecting cliff, they had the village in reach of their voice each evening. As in later phases, and to conform with Dogon standards 
of interpersonal communication, they played down thcir own role. extolled the virtues of thrse who turned out on previous occasions, shamed the lazy ones, throughout stressing the reciprocal dependencr of old and young, men and women.

The demographical situation before the European arrival is hard to assess. Probably it would have had a standard pre-transition patten, with a high natalty, a high mortality and little consequent population growth There is no evidence of natality restriction in that perod (there is still hardly any today). Slave raiding would have formed the most important mechanism of population restriction. either by the direct transferral of men and women from the densely populated falase area, or by a specific institution that developed in response to it: any mother's brother had the right to sell his sister's daughter in slavery. This most often happened when raiders had captued somcone's brother, son or wife, captives which coukl be ransomed for a sister's daughter. From the angle of demogtaphy this is highly effective, as the abduction of these nubile young females drastically diminished Dogon reproduction.

\section{TIE COLONIAL, TRANSITION}

The advent of the colonizer brought about some fundamental changes that. at an accclesating pace, transformed Dogon adaptation. The par gallica cut short the slave raiding in the area as well as the (few) skurmishes between Dogon settlements themselves. This resulted in the plateau as well as the plains becoming avalable for cultivation At an ever increasing rate the Dogon swarmed out into the newly opened tcrritories, bulding new farms and founding new villages. Plains and plateau were not exactly empty; some villages had already been established on the plans', as well as on the plateau. Still. in the first decades of the century the Dogon quickly filled in the empty spots on the map. first along the present border with Burkina Fasso with its better soils, then in the sandy plains closer to the escarpment. On the plateau the Dogon drifted in a northwestern direction. For the villages at the falaise, on which we are concentratung, this emigration at first resulted in a sparser population. Also, some of the pressure on land was eased owing to the cultivation of distant fields, which were st1ll considered to be village terntory. In the falaise villages, new fields at 5 to 10 kilometres from the $1 \mathrm{im}$ were brought into cultivation. The control of those fields fell to the families that ventured out, first collectrvely as agnatic lineages but also individually. So, in contrast to control of the in-fields by the gerontocratic structure, these out-fields were owned by families.

At the same time new crops were being introduced. Tobacco had been grown for a long time, but onions came to be cultivated on a rapidly increasing scale. Thus a dry season cultivation developed, in which the onions (and tobacco) were cultivated in the river-bed, irrigated with hand-carried pots and calebashes. Waterholes were dug on several places in the sand, to follow the receding water table during the three months of onion cultivation (December to February). Villages on the plateau grew onions at the border of the few places where an impermeable layer in the rock retained a pool of stagnant water during the dry season. This onion production was the first real cash crop for the Dogon, triggered by the need for money (taxation and the purchase of commodities) and the presence and development of food markets. The onions were readily accepted in the region.

This first colonial phase was characterized by pacification, dispersal and very little investment in the area, and lasted to about the Second World War. Socially, it was a period of moderate fragmentation. The traditional survival strategy of communal labour lost most of its rationale, though it did not entirely disappear. Individual property became more important, though this was not new for the Dogon. The influence of the old men as a body diminished, as their collective co-ordinating role in agriculture dwindled. Yet they remained important in village matters and regulated the large communal tasks for the whole village. However, with the relative privatization of land use and ownership, their importance within the extended family was strengthened, as they gained control over the out-fields through the lineage system. The extended families themselves gained in importance as they grew less dependent on cooperation with other extended families. Besides, the constrained labour the colonizer demanded and recruitment for the army meant a demand for labour that extended families could very well cope with. Production in the onion gardens depended on the individual or the nuclear family. As this production complemented the general subsistence, it left the position of the old men untouched.

The second colonial period, from the late 1940 s up to the 1970 s, is characterized by a decrease in small-scale and an increase in largescale migration. While the plains gradually were filled up and the people began to settle in the dune areas closest to the villages, labour migration, after a slow start before the Second World War, began to be quite important. Young men were first allowed and 
50 An anthropological critique of development

later expected to work a stint in the large cities of the West African coast, such as Accra or Abidjan. Dogon labourers gained a reputation as eager and resourceful labourers, and easily found employment. A work period lasted between one dry season and several years, and brought most of them back to their falaise village loaded with modern commodities such as radios, bicycles, clothes and, of course, money. Monetarily the villages grew dependent on this labour migration.

Onion farming became more important, especially on the plateau, where after a successful start in 1938 an ever increasing number of small 'barrages' (small dams) were built. Dozens of small man-made lakes enabled the plateau Dogon to concentrate on onion farming in an environment where formerly no cultivation - and not even grazing - had been possible, a point to which we shall return later.

Ecologically this is the start of the desertification of the plains. The sandy dunes adjoining the escarpment began to be overcultivated, beyond their carrying capacity. The shifting cycle of the outfields was gradually shortened and the supply of fire and construction wood became scarcer. Dogon agriculture intensified, concentrating on three focal points: the falaise rim and the out-fields in the wet season, and the waterholes in the dry season. This intensification, combined with the filling up of all ecological niches in the area, put the eco-system under an increasingly severe strain As the resources were closing, new kinds of limitations appeared. Fertilization of the soils became more problematic, as the onion and tobacco farming demanded ever more manure. The traditional ways of manuring telied on the residue of the subsistence farming on the one hand and on animal husbandiy on the other. So an increase in cattle can be noticed in this period, which in turn put the ecology of the area as a whole under pressure and endangered the natural refertilization within the jachère system of the out-fields.

Demograplic pressure aggravated the situation. The Dogon population rose from an estimated 100,000 at the turn of the century to at least 300.000 in the early 1970 s. Outmigration became increasingly important, starting from the strongholds established by the migrant workers in the cities.

Socially this period showed the flexibility of the family structure. The extended family shifted from a patriarchal one to a flexible coopting of related nuclear families, a community of interests in which the second generation took precedence. During the wet season, when labour was very much in demand, the whole family lived and worked together, cultivating their joint millet fields. The dry season
Processes and limitations of Dogon agricultural knowledge 51

onion cultivation, then, split the family into nuclear ones, on a basis of restricted profit sharing. When the out-fields were too far away from the village, or when one of the sons had settled in a plains village, the extended family remained a single financial unit: both the plains and the escarpment parts of the family contributed to its common fund. This kind of non-resident extended family proved to be very fiexible in both arranging labour and meeting expenses as well as profiting from the variegated resources of the region. Most years show a fair difference in agricultural success between plateau, escarpment and plains; so spreading out the family enhanced chances for survival in an ecological system that proved to be less and less dependable.

The old men lost some of their importance, though they retained control over the in-fields, over the finances of their families and over ritual. As onion farming, for example, gave rise to new cooperating groups (like the group of people using the same waterhole) the network of relations in the village grew more diffuse. Still, as kinsmen tended to live close together and peers tended to cultivate together, the warp and woof of lineages and age groups remained dominant in the escarpment villages.

\section{BREAKING UP THE SYSTEM}

Since the late 1970s the pressures on the ecosystem have dramatically increased. The drought that set in around 1973 in West Africa hit the Dogon area after 1980, culminating in the disaster years of 1984 and 1985. Though local differences are considerable, even on the small scale of the Dogon region the whole picture is one of gloom. The fact that the good rainy season of 1986 was spoiled by a locust plague in several villages intensified this feeling. Villages that dwindled during the outmigration to the plains are being deserted completely. On the plateau, and especially in the plains, the villages have become the centres of wide circles of desert, where the combined efforts of man and cattle have stripped the soil of its fragile vegetative cover. Migration has started towards the south of Mali, in Bambara country, and towards the Mossi area of Burkina Fasso. This migration, aided by the Malian government and several NGOs working in the region, is, of course, the sign of ecosystem failure.

Still, neither the Dogon nor aid agencies give up that easily. Aid is pouring into the Dogon area from various sources in several ways. Food aid is one form, the construction of 'barrages" another. Before 


\section{An anthropological citique of development}

going into this problem, however, we have to glean some insights into how the Dogon construct the ecological reality, how they view their environment.

\section{DOGON AGRICULTURAL KNOWLEDGE, GENERAL AND SPECIFIC}

Dogon agricultural knowledge is the result of a long interaction with their physical envitonment, both with those aspects that remain more or less constant and with the changes that their ecological history has brought about. Their perception of the ecology can be described as a general perspective on their relation with their environment on the one hand, and on the other as a set of procedures to obtain highly specific local knowledge through interaction with that environment.

The general view is one of unlimited resources. There is no scarcity of land according to the Dogon: 'there is plenty land in the plains". The people living on the escarpment in particular vicw the plains as long stretches of bush more or less empty of habitation. The same holds for wood, another increasingly scarce resource. Trees ane still considered to be available in relative abundance. If one cannot easily find a field, or trees, it is simply a question of going a little bit further, walking another hour. That this view does not correspond with the way the plains nowadays are filled up with villages and hamlcts, and with the rapid disappearance of substantial trees (the fitewood zones of the villages start overlapping each other) is not relevant. The old image from the falaise, from the times of the slave raiding, is that of a seemingly endless emptiness, a sea of uninterrupted yellow or green gently undulating land, dangerous because of human and supernatural beings, but waiting for the human hand to exploit and cultivate it. An area to be colonized, in short.

Thus an important opposition is the one between the village habitat and everything else: ana (village) versus oru (bush). One is safe in the village, whtle never fully at ease in the bush. The bush is the old 1aiders' territory, and before even that, was the region of spirits. Though most of these are not thought to be malevolent, therr very presence is eery and annoying. Besides, evil humans (van Beek 1993) such as witches (yadugonu) and sorcerers (dudugonu) roam the bush after dusk. At night one should be protected, isolated from the influences of nature, within the village, sleeping not on top of the roof (a bird might pass over the sleeping figure, possibly
Processes and limitations of Dogon agricultural knowledge 53 causing harm with its spirit), but safely within the confines of a house or under a lean-to. In the Dogon view the village in which one is safe and secure is surrounded by an inhospitable vastness of bush. This oru can be cultivated with a lot of exertion but in itself it stays untamed. Beyond the village perimeter things are not domesticated, but have to be 'tamed' over and over again. The dangers of the bush are not evenly divided over the area: places near water are dangerous, and so are stands of trees. The way to tame the bush is to build houses, grass lean-tos at first, more permanent houses later, if possible within sight of other settlements. Fellow humans are preferred as companions over the 'things of the bush'. ${ }^{2}$

For the Dogon it is the humans that are in short supply, not the fields. Their system is an expansive one, in which more people are always needed, mole fields have to be taken into cultıvation, more cattle raised. Fertility is highly valued. In their yearly wotk-cycle this notion of labour shortage is understandable: during the cultivation season, especially when weeding, labour in fact is in short supply, and every hand is needed. The rest of the year, however, this is not the case. Onion farming, of course, with its heavy demand for labour, has served to reinforce this attitude. Like humans, animals are in short supply, and with animals, manure. For the Dogon manure is one of the limiting factors in agriculture, and most cattle are seen primarily as dung machines. So increase in animals means new opportunities for cultivation.

This general view of environment in a way presents a cultural lag, as we noted, but one that is more than simply a time lag in understanding new conditions. This vision of availability of resources is central to the Dogon attitude towards their survival, and in itself has been instrumental in their relative success so far. Tied in with the vision of the wide open spaces, is a special version of a frontier mentality, a vision of riches waiting to be explored and put to use. The specific way in which this is crystallized in Dogon culture is through a set of expectations and practical procedures in dealing with that environment.

Given this notion of open resources, the question is whether they can be mastered, and secondly, how. Consequently, the Dogon view of their environment stipulates two criteria: whether parts or aspects of their surroundings are 'manageable' or not, and whether they are 'usable' or not. The first criterion decides if - in the opinion of the Dogon - one can 'do something about' it, if one is master of this part of the environment. This does not always imply that production 
should result from the human interference; any kind of change will do. The hand of the Dogon should be visible. The environment is sized up as to whether one can 'make something of it', or as the Dogon expression goes, if one can yegere, arrange matters, put things straight. The difference between an environment brought into harmony with the people living in it, and one where this is not done, is clucial.

The second critenon, 'being usable', decides whether something productive can be done with the environment. If a stretch of land, a field for instance, can bring about a substantial crop, it is usable. If a similar stretch of land would not yield much crop at all it is unusable. The Dogon terms for this distinction are simply 'good' and 'bad'. The same holds for rocks that can be used for building, and those boulders that cannot be split up, or put to any other use.

The first criterion is crucial. On the whole the Dogon consider their environment manageable if people work, if they truly exert themselves. they can shape their own basis of living, their survival, subdue the untamed busl. A strong work ethic is part of this view: one who works, survives Thus they can perceive a much larger proportion of the environment as manageable than would be expected by an outsider. Of course, the basic elements, the escarpment, the plateau, the acree and dunes are given entities, but within this large cadre most things ate not given. For an ascent up on to the plateau, for instance, the Dogon are not content to be dependent on nature, where there is no ascent, they make one, shattering latger houlders with then self-fabricated gunpowder into mediumstzed rocks. and installing ladlcts and ropes. Building houses on the scree involves shattering latge rocks, shapung them into convenient sizes, before even statting to build. Another, individual. example someone who nceded water for his cattle asked where he could find water The answer was that he could find it at a depth of mo metres His teactunn no problem, that is just two months digging (1 mete a day) I Akewise, according to the Dogon any field (an be culturted. of only perple exert themselves in manuring it.

The second criterion. whether a particular part of the environment (an be used or not is of course partly dependent on manageability, lut bot wholly so For instance, the stretch of land just beyond the III field zone is not used for cultivation. because. accoiding to the Jongnn, the land is not good Manumg uould help, but that is not presible bec nuse of lack of crulc In therr view the land has hardly erer heen used at all Strll, ieseatch on aerral photogiaphs and sol inmprsituon leveals that the fields have heen used very mensively, in fact have been overused, in the past. Their depletion has made regeneration very slow. Another, quite spectacular example is onion farming on the plateau. The Dogon are justly famous for it. When water is trapped behind a barrage, the Dogon have the immediate border of this small man-made lake to cultivate. Often this is just naked rock. From kilometres away they bring in soil to lay on the rock. Then small stones are sought, cut and lined up in order to mark out the cultivation squares. Manure and fertilizer are added to the soil, and finally the bulbs are planted. Then the actual work starts, watering the fields by carrying pots or calabashes from the well or lake to the field, each full morning for three months. It is a Herculean task, but one deemed normal for the Dogon. So even the inhospitable rock is in principle usable, and - if so defined the Dogon will yegere, manage, too, in order to make it usable.

Within this framework, the agricultural knowledge of the Dogon is practical, factual, detailed and personal. Their knowledge includes a detailed distinction between many minute varieties of the main crops. especially millet. They distinguish on the basis of smell and taste, as well as adaptability to specific terrain, even specific fields. In the in-fields mixed cultivation of several crops is guided by a detailed view on what crops should go together and which definitely not. Rotation in the out-fields follows a distinct pattern (beans, millet, millet, fonio). The start of the cycle, the end of the fallow period, is indicated by specific grasses appearing on the fields. The end of the cycle is shown by the emergence of specific weeds between the millet or sorghum. The start of the cultivation season is known by both counting moons, watching the exact spot of the sunset and waiting for the migration of a specific bird (ana sasa). During the cultivation season, the Dogon farmers are guided by a detailed knowledge of manure, both for the millet fields as well as for the onion patches.

This knowledge is practical. As subsistence farmers the Dogon are survival oriented, aiming at - in western terms - an optmization of the chances for survival, not at a maximization of the harvest. They do so by spreading risks; sowing several sorghum varieties, maize, groundnuts, fonio, sesamum, even rice, with their main crop of millet they are sure that though certanly some crops will not yield a harvest, some will. For the millet, their mainstay for survival, which is best adapted to dry conditions, they choose several varieties with differing drought resistance, some will yield. Agriculture is to do with survival, not profit, a tendency which does not make them 
rich, but has the great advantage of keeping them alive, as it has done throughout the past centuries.

Knowledge is factual and detailed. The Dogon have a crystallized view of the general characteristics and exigencies of each of their crops; what amount of rain is needed, the dangers they run from crop diseases and parasites, the amount of manure needed, the way in which one crop combines with others, etc. In even more detail, Dogon farmers know from the look of each field what has been grown on it, what the yield was, what manure serves best and how much weeding is needed. They know what plants should appear before starting cultivation in general, and where to expect those grasses on that particular field. They know the slight depressions in the dunes where they can bury a pot to catch some rain for drinking when out in the fields for days. When tending their onion gardens, they know at what stage of growth what type of manure is to be used (they distinguish between at least eight different types of fertilizer, ranging from goat dung to termite mounds, from guano to pounded phosphate-holding rocks), and they know when the bulb is mature by judging the state of the flowers.

Knowledge is personal. A farmer has this knowledge about his own fields, the fields he uses. When the fields change hands, the former uscr is expected to indicate the best use of the field to its new 'owner'. As the fields fall into well-definable categories (scree, valley floor, in-field dune, out-field) this personal knowledge consists of some details per field, on top of the general knowledge pertaining to that paticular terrain.

The above mentioned qualities make for a very open system of local knowledge. Though some generalization as to categories of fields, crops and other resources are made, the focus is on the individual and his or her knowledge of his or her personal environment. Local knowledge, at least in agriculture, is less dependent on "tradition' (whatever that may be) than on personal experience; it is a process of information selection and evaluation, more than a body of ready-made notions and values. Trial and error is much more important than fixed ideas, as the system of acquiring knowledge is definitely non-scholastic.

Thus. local Dogon knowledge quickly incorporates new elements. The precise knowledge gained on crop rotation and soil refertilization can serve as an example. Out-field cultivation started this century and the related detaled, practical knowledge must have been generated in that restricted time span. Characteristically, the Dogon emphatically state that they have 'always known it', a state- ment indicating - in my view - the social value and respectability of that body of knowledge (they use the same expression when describing new rituals that have been incorporated). A more recent example is onion farming. The know-how, which is considerable, has been built up in decades, not in centuries. Thus a relatively new problem with onions - storage - has not been resolved yet and still is in the first trial-and-error phase. Finally, a totally new crop, such as the water-melons grown in a falaise village for three years, presents a new problem for the Dogon: detcrmining when the melon is ripe is difficult, and the Dogon have as yet not found the clue (the people in the inner delta of the Niger have no problem at all in this respect).

The Dogon expression for knowledge is just as flexible: 'knowing the word'. On the one hand this points to the function of words in traditions, for knowing the stories of migration and strife that led to the existence of the Dogon at the falaise. On the other hand it means simply 'knowing the language', that is, knowing the ways to formulate new thoughts. Both aspects, the traditional as well as the everyday are about equally important in Dogon society. There is, however, some notion that women focus more on the practical, flexible words $(s \grave{\partial})$, and men more on the traditional, fixed words.

So two aspects of Dogon agricultural knowledge can be discerned. They view their ecosystem as stable, even if geared to a situation of the past. Rituals and some myths form part of this collective memory, this fixed knowledge. This part of the Dogon view of the environment is part of a long-standing historic process. In the paragraph on history we sketched the main challenges on Dogon society up to the present. They have lived for centuries in a situation where tesources were visible but out of bounds. where the main restriction on adaptation was manpower. The Dogon answer was to collectivize labour and to privatize knowledge. Within the general framework of their overall view of their environment. this specific and privatized knowledge in combination with the joining of labour forces proved highly adaptive. It enabled them to fill effectivcly all possible niches in their environment, as individuals ultimately decided on the use of any particular resource. This combination, which is just the opposite of the course western society has charted, also allows for a very flexible input of labour. It was essential that this privatization was founded not on a body of fixed knowledge but on a system of permanent information assessment, a procedure to gather, evaluate and implement practical, detailed and smallscale information. One cost could have been that this practice 


\section{An anthropological critique of development}

allowed some things to be forgotten, such as the results of past trials and errors. However, the collectivization of labour might have mitigated this tendency somewhat. Still, the gap between the inflexibility of the general view and the flexibility of the privatized knowledge is apparent, and there seems to be no intermediary betwecn these two fields of knowing. The traditional general knowledge is not confronted with the personal, flexible information and temains unchallenged. This fits in with a general characteristic of Dogon thinking, as exemplified in their religion, namely its cumulative, non-systemic character (van Beek 1982). Diverging notions are not reasoned out, and new elements can be introduced without change in the whole system. Just as there is no theology in Dogon religion, there is no systematization of Dogon ethno-science. This may put a question mark over some fundamental anthropological ideas on cultural integration.

One major problem is that of scale. The combination of private knowledge and public work works well in small-scale society, with a reasonably slow rate of change; there, personal experience not only seems but often in fact is the most reliable source of information, and the personal experiences of the various members of society do not diverge too much. Up into the late colonial period the Dogon villages were pretty much autonomous units, where the ecology of one village (especially the scree villages) was the microcosm of the ecology of the whole group. This system is breaking up, as we explaned before. Foregn aid has built at least fifty-five bauages on the plateau, and many more are under construction. This, combined with the difficulties in growing cereals in the dry years of the recent past. has changed the ecology of the plateau villages. Quickly, they ane becoming onion farming villages. No longer docs the money gained from onion farming serve as a finatcral supplement for a subsstext unit. Now cereals, millet and sorglum bave to be bought at the market in order to feed the family In omon farming, fertilizes. bought though government cliannels. replaces manuic. The tesult is that wherever barrages are present villages are built The plateau attracts a population at a level well alove its pescnt carrying capacty in subsistence The farmers become wholly depcndent on the external onion market and on the supply of feltulyer The no longet have contsol over their fields, as these are provided for by foreign ald. for the construction as well as mapor manterance of the dams This ptocess, which I have called rultual polstanzation flsewhere (van Beek 1986) is easily
Processes and limitations of Dogon agricultural knowledge 59 discernible in the larger settlements. The smaller villages with restricted water storage still have a more mixed economy.

The subsistence food for the plateau has to come from the plains. There villages concentrate on growing millet, and in the good years do so with good results. The development of a market for millet, formerly only produced and consumed within the extended family, has led to extensive millet production. More land has come under cultivation, fallowing periods are being shortened, so the strain on the environment is growing, and the desert is close.

It is on the escarpment that both parts of the Dogon ecology still are in some balance: subsistence cultivation-cum-onion farming; this may be due in large part to emigration. Another reason may be that the escarpment is out of reach of motorized transport, which stimulates cash-crop farming. However, here drought (and locusts in 1986) have struck more often than among the other villages. Thus, present Dogon villages no longer are a microcosmic representation of the whole area. Most of them represent one variation in an interdependent system with specialized parts. The problem then is, that the fixed knowledge of the general view of environment as well as the specific systems of knowledge have no way of coping with the larger scale of Dogon society. Within the local situation the traditional attitude may be adequate, but it can be destructive for the system as a whole.

This implies that ignorance in Dogon agricultural knowledge has at least three aspects. First, several parts of their environment are not stipulated as part of the (agri)cultural process and, as such, may be irrelevant, and are kept out of the information-processing. For some period the zone between the in-fields and the out-fields remained beyond attention: people simply did not bother about it. Second, new elements are still in the trial-and-error stage; the cultivation of water-melons may serve as an example. Finally, the most important lack of information is the inability to cope with information beyond the community level. For development purposes all three causes of ignorance are relevant, though the ignorance of scale' is by far the most important.

It is this problem of scale that leads towards destructson of the ecosystem in the plains, and a very rapid one at that. On the plateau the Dogon general view and local knowledge stimulate an ever increasing and intensifying onion culture, to the detriment of their own chances for long-term survival. At the falaise it leads to the desertion of those villages where the conditions for survival actually may be best. Thus, the very survival value of Dogon knowledge 
60 An anthropological critique of development

processing leads towards a strategy in which the means for present survival endanger their existence in the long run. This sacrifice of the future for the sake of the present is a typical feature of peasantification and of cultural proletarization.

\section{NOTES}

1 Research among the Dogon has been carried out in 1979-80, 1982, 1983 1984, 1985, 1987, 1989 and 1991 and made possible through grants of the National Foundation for the Advancement of Tropical Studies (WOTRO), the University of Utrecht, Time-Life, Agence Aigle and Dutch Television (VPRO).

2 For a more extensive treatment of the Dogon view of their environment see chapter by W. E. A. yan Beek and P. M. Banga in E. Croll and D. Parkin (eds) (1992) Bush Base: Forest Farm - Culture, Environment and Development. London: Routledge.

\section{REFERENCES}

Bedaux, R. M. A. (1982) 'Tellem, reconnaissance d'une civilisation prélistorique', Journal de la Société des Africantstes 23 (2): 113-34.

van Beek. W. E. A. (1982) Spiegel van de mens: Religie en Antropologie, Assen: Van Gorcum.

- (1986) 'L'état ce n'est pas nous: cultural proletarization in Cameroon' W. yan Binsbergen, F. Reyntjens and G. Hesseling (eds) State and Local Communty in Africa, ASDOC Studies 2-3-4: 65-88.

- (1993) 'The innocent sorcerer: coping with evil in two African societies (Kapiski and Dogon)', in T. D. Blakely, W. E. A. van Beek and D. L. Thompson (eds) Religion in Africa Experience and Expression, London: J. Currey

Bryson, R. A. and Murray. T. J. (1977) Clmates of Hunger, University of Wisconsin Press

Dieterlen, G. (1942) Les Ames des Dogons, Paris: Presses Universitaires de France.

Hardesty, D. (1978) Ecological Anthropology, New York: Wiley.

Paulme, D. (1948) L'organtsanon sociale des Dogon, Parrs: Presses Universitalres de France.

Smaldone, J. (1978) Warfare in the Sokoto Caliphate: historical and sociological perspectives, Cambridge: Cambridge University Press.

\section{Cultivation: knowledge or performance?}

\section{Paul Richards}

\section{AGAINST LOCAL KNOWLEDGE}

It is a characteristic feature of the oneness of the modern world that indigenous cultivation should have come to be thought of as grounded in local knowledge. To technologically-minded improvers this local knowledge is often or mainly outmoded, and something to be replaced. Anthropological romantics, by contrast, in establishing their credentials as priests of humanistic plurality, are apt to celebrate it. Both groups are thereby liable to credit local knowledge of agriculture with a spurious epistemic independence, as if it were the regular outcome of a process of 'peasant intellectualism' parallel in some way to the processes of intellectualism operating in North American or European academic life. Intellectualist movements arise from time to time within communities of small-scale cultivators (Feierman 1990, Richards 1992) but their achievements are dangerously undervalued by assuming that small-scale cultivators neces. sarily abound in agro-ecological wisdom. This assumption seems to me to run the risk of ethnocentricism. Stephen Marglin (1991) has drawn attention to the historically localized peculiarities that led to a rather strict segregation between episteme and techne as forms of knowledge in western society. Nineteenth-century Victorians, for example, had good reason to try to insulate the reflective privileges of intellectuals from the authority claims of builders, plumbers and other purveyors of practice in a world undergoing rapid material transformation (cf. Galton's statistical work on the absent-mindedness of professors, gaze averted from the contents of their breakfast tables, their attention devoted to higher matters). But I see no reason why anthropologists should continue to stigmatize cultivators with an intellectual dichotomy redolant of the class-based parochialism of later-Victorian imperialists. 